\title{
Risk Management Strategy on Shallot Farming in Bantul and Nganjuk Regency
}

\author{
Fuad Hasan ${ }^{1 *}$, Dwidjono Hadi Darwanto ${ }^{2}$, Masyhuri², Witono Adiyoga $^{3}$ \\ ${ }^{1}$ Department of Agribusiness, Faculty of Agriculture, Trunojoyo University, Madura \\ Jln. Tellang, Kamal, Bangkalan Regency, East Java 69162, Indonesia \\ ${ }^{2}$ Department of Agricultural Socio Economics, Faculty of Agriculture, Universitas Gadjah Mada \\ Jln. Flora no. 1, Bulaksumur, Sleman, Yogyakarta 5528, Indonesia \\ ${ }^{3}$ Indonesian Vegetable Research Institute \\ Jl. Tangkuban Perahu 517, Lembang, West Java 40391, Indonesia \\ *Corresponding email: fuad.hsn@gmail.com
}

Received: $5^{\text {th }}$ August 2016 ; Revised: $10^{\text {th }}$ August 2017 ; Accepted: $10^{\text {th }}$ August 2017

\begin{abstract}
The objectives of this research were to understand farmers' perception to risk and risk management strategy on shallot farming. The research was conducted in Bantul and Nganjuk Regency. The number of samples taken were 57 farmers in Bantul and 90 farmers in Nganjuk. Analysis used was frequency table that disaggregate based on agroecosystem and cropping pattern. The result showed that according to farmers' perception, production and price risk were high. Farmer's decision to follow dominant cropping pattern and production system reflected on the ex ante risk management strategies done by the farmers as their own respection. In the interactive risk management strategies, farmers tended to use chemical fertilizers over chemical pesticides. In ex post risk management strategy, in the failure of shallot farming, they kept cultivating shallot that their capital got on cash and input for shallot farming.
\end{abstract}

Keywords: Ex Ante, Ex Post, Interactive, Risk Management, Risk Perception

\section{INTRODUCTION}

Uncertainty and risk are quite essential features in agriculture. Musser and Patrick (2001) followed Baquet et al. (1997) and define five major sources of risk in agriculture. Production risk concerns variations in crop yields and in livestock production are due to weather conditions, diseases and pests. Marketing risk is related to the variations in commodity prices and quantities that can be marketed. Financial risk relates to the ability to pay bills when due, to have money to continue farming, and to avoid bankruptcy. Legal and environmental risk concerns the possibility of lawsuits initiated by other businesses or individuals and changes in government regulation related to environment and farming practices. Finally, human resources risk concerning the possibility that family or employees will not be available to provide labour or management.

Risk can not be eliminated but can be reduced through a risk management. For individual farmer, risk management involves finding the preferred combination of activities with uncertain outcomes and varying levels of expected returns. Risk management strategy can be devided to ex-ante, interactive, and expost strategy (Adiyoga and Sutiarso, 1999). Ex ante strategies adopted before a risky event occured can reduce risk. Ex post strategies adopted to cope with losses from risks that have already occurred (Sen and Choudary, 2011). Musser (1998) concluded that the geographic location and environment have an influence on the perception of risk and risk management carried out by farmers.

The objective of this research are to understand farmers perception to risk and risk management startegy of farmers.

\section{MATERIALS AND METHODS}

This research were conducted in Bantul (Yogyakarta) and Nganjuk Regency (East Java) from May to June 2014. Based on its agroecosystem, Bantul had two kinds of agroecosystem, i.e. wetland and coastal sandy land. Meanwhile, Nganjuk only had wetland 


\begin{tabular}{|c|c|c|c|c|c|c|c|c|c|c|c|}
\hline \multicolumn{12}{|c|}{ Coastal sandy, Bantul Regency } \\
\hline 1 & 2 & 3 & 4 & 5 & 6 & 7 & 8 & 9 & 10 & 11 & 12 \\
\hline & \multirow{2}{*}{\multicolumn{4}{|c|}{ Horticulture non shallot }} & \multicolumn{3}{|c|}{ Shallot I } & & & \multirow{2}{*}{\multicolumn{2}{|c|}{ Shallot II }} \\
\hline & & & & & & \multicolumn{4}{|c|}{ Hot pepper } & & \\
\hline \multicolumn{12}{|c|}{ Wetland, Bantul Regency } \\
\hline 1 & 2 & 3 & 4 & 5 & 6 & 7 & 8 & 9 & 10 & 11 & 12 \\
\hline \multirow{2}{*}{\multicolumn{2}{|c|}{ Paddy }} & \multicolumn{3}{|c|}{ Shallot I } & & \multirow{2}{*}{\multicolumn{3}{|c|}{ Shallot II }} & \multirow{2}{*}{ fallow } & \multirow{2}{*}{\multicolumn{2}{|c|}{ Paddy }} \\
\hline & & & \multicolumn{3}{|c|}{ Hot pepper } & & & & & & \\
\hline \multicolumn{12}{|c|}{ Twice/year, Nganjuk regency } \\
\hline 1 & 2 & 3 & 4 & 5 & 6 & 7 & 8 & 9 & 10 & 11 & 12 \\
\hline \multicolumn{3}{|c|}{ Paddy } & \multicolumn{2}{|c|}{ Soybean } & \multicolumn{3}{|c|}{ Shallot I } & \multicolumn{3}{|c|}{ Shallot II } & \\
\hline \multicolumn{12}{|c|}{3 times/year } \\
\hline 1 & 2 & 3 & 4 & 5 & 6 & 7 & 8 & 9 & 10 & 11 & 12 \\
\hline \multicolumn{3}{|c|}{ Paddy } & \multicolumn{3}{|c|}{ Shallot I } & \multicolumn{3}{|c|}{ Shallot II } & \multicolumn{3}{|c|}{ Shallot III } \\
\hline \multicolumn{12}{|c|}{4 times/year } \\
\hline 1 & 2 & 3 & 4 & 5 & 6 & 7 & 8 & 9 & 10 & 11 & 12 \\
\hline \multicolumn{3}{|c|}{ Shallot I } & \multicolumn{3}{|c|}{ Shallot II } & \multicolumn{3}{|c|}{ Shallot III } & \multicolumn{3}{|c|}{ Shallot IV } \\
\hline
\end{tabular}

Figure 1. Cropping Pattern in Bantul and Nganjuk Regency

agroecosystem. Based on the dominant cropping pattern, farmers in Bantul cultivated shallot twice a year, while farmers in Nganjuk done the cultivation twice or more a year. The numbers of samples taken were 57 farmers in Bantul and 90 farmers in Nganjuk. Analysis used was frequency table which disaggregate based on agroecosystem and cropping pattern.

\section{RESULT AND DISCUSSION}

\section{Cropping Pattern}

There were some differences in shallot growing season between Bantul and Nganjuk. First, growing season in Bantul was started on March (wetland) and June (coastal sandy), while in Nganjuk, the growing season was strated on April by farmer who cultivated more than twice a year and June by farmers who cultivated more than twice. In addition, there was differences in the second growing season. An abbondan shallot harvest occur in August and September.

\section{Risk Perception}

There was yet consensus existed on the notion of risk in scientific literature. Different domains of science applied different concepts of risk. These concepts of risk could be grouped according to the epistemological foundation (Zinn, 2009). Some authors argued that risk did not exist beyond it being a psychological construct (Sjöberg et al. 2004).

From a realist perspective, it was assumed that "real risk" could be measured objectively. Individual perceptions of risk, however, differed from one person to another. This difference, as we would see, could not be explained solely by the imperfect knowledge on the real risk being observed. Moreover, individuals had different perceptions of reality because of their different interpretation of reality. For all perceptions of reality, brain was filtering the incoming information. This filtering process was strongly related to social and cultural background, and personal history of each individual (Proske and Proske, 2008). Risk perception was a mental interpretation of the physical sensations produced by an external stimulus. They were thus not permanent and were shaped if new information was obtained (Senkondo, 2000).

Farmers also defined the risk of farming with different perceptions (Table 1). Most farmers in Bantul (46\%) and Nganjuk $(45,6 \%)$ defined risk as everything that might result in the financial loss of shallot farming. Some of them considered that risk was everything that might endanger the profitability of shallot farming, but the impacts could be prevented or reduced if farmers were cautious from the beginning.

According to Bantul and Nganjuk farmers, there were a common perception that farming failure happened when production and prices obtained were relatively low (50\% and 55,6\%). However, Nganjuk farmers prioritized price $(28.9 \%)$ more than production $(16.7 \%)$ as an indicator of success or failure in farming. On the other hand, Bantul farmers prioritized production than price. This was related to post-harvest management. Almost all shallot farmers in Nganjuk did not have 
Table 1. Farmers' Perceptions Regarding Risks in Shallot Farming

\begin{tabular}{|c|c|c|c|}
\hline No & Farmers' Perceptions & $\begin{array}{c}\text { Bantul } \\
\mathrm{N}=78(\%)\end{array}$ & $\begin{array}{l}\text { Nganjuk } \\
\mathrm{N}=90(\%)\end{array}$ \\
\hline \multicolumn{4}{|c|}{1 Risk as perceived by farmers } \\
\hline & $\begin{array}{l}\text { a. things that may cause the occurrence of unexpected low } \\
\text { shallot production }\end{array}$ & 3 & 3 \\
\hline & $\begin{array}{l}\text { b. everything that may result in the financial loss of shallot } \\
\text { farming }\end{array}$ & 46 & 46 \\
\hline & $\begin{array}{l}\text { c. everything that may endanger the profitability of shallot } \\
\text { farming, however the impacts can be prevented or reduced } \\
\text { if farmers are cautious from the beginning }\end{array}$ & 33 & 33 \\
\hline & $\begin{array}{l}\text { d. consequences for farmers in cultivating shallot, such as } \\
\text { providing capital, making inputs available, etc }\end{array}$ & 18 & 18 \\
\hline \multicolumn{4}{|c|}{2 Farming failure as perceived by farmers } \\
\hline & a. relatively low yield of production & 28 & 16.7 \\
\hline & b. relatively low price of output & 22 & 28.9 \\
\hline & c. relatively low yield and price of output & 50 & 55.6 \\
\hline \multicolumn{4}{|c|}{3 Production risk of shallot farming as perceived by farmers } \\
\hline & a. high & 77 & 76.7 \\
\hline & b. moderate & 23 & 17.8 \\
\hline & c. low & 0 & 4.4 \\
\hline \multicolumn{4}{|c|}{4 Price risk of shallot farming as perceived by farmers } \\
\hline & a. high & 69 & 73.3 \\
\hline & b. moderate & 29 & 21.1 \\
\hline & c. low & 1 & 3.3 \\
\hline \multicolumn{4}{|c|}{$\begin{array}{l}5 \text { Farmers'reasons for cultivating shallot, even though it is } \\
\text { very risky }\end{array}$} \\
\hline & a. risk impacts can be reduced or prevented & 41 & 35.6 \\
\hline & b. experience has shown that there is a limited choice & 13 & 14.4 \\
\hline & c. cultivating other crops is considered riskier & 1 & 4.4 \\
\hline & d. provide more revenue expectation & 42 & 40.0 \\
\hline
\end{tabular}

a habit to bring the crops home, but they tend to sell their crops in the fields with a tebas (buy crop before harvest) mechanism. This caused farmers great loss when shallot price was relatively low since they could not delay the sale. Unlike farmers in Bantul who always brought their crops home and did some post-harvest handling, such as drying and cleaning of dirt, so that there was little added value and to arrange sale time though it was no longer postponed due to recessive needs.

According to Patrick et al. (1985) and Wik et al. (1998), an important source of risk faced by farmers was the production and price risks. The results showed that the perception of most shallot farmers in Bantul and Nganjuk assumed that production (77 and $76.7 \%$ ) and price risk (69 and $73.3 \%$ ) were high. The high risk production indicated that production technology had not yet fully mastered or applied by farmers. Many farmers did not use certified seed, unbalanced fertilizer application, and shallot cropping pattern yearly. The price risk considered by farmers indicated that the price was really beyond the control of farmers and an external factor.

Although shallot farming was considered risky, farmers still grew shallot from year to year because they thought shallot farming provided a great revenue expectations.

\section{Risk Management Strategy}

a. Ex Ante Risk Management Strategy

Risk management strategy pursued by farmers before appearing of risk was basically shown to reduce variability revenue. Figure 1 showed the dominant cropping pattern done by Bantul and Nganjuk farmers. Based on the experience of farmers, such cropping patterns were most profitable.

In the first growing season, shallot farmers in Bantul cultivated shallot using intercropping system with red chilli. According to farmers, intercropping system could obtain a big income, made efficient use of inputs, and anticipated the losses on shallot plants and wait for the right time to plant shallot in the next season. In the second growing season, farmers did not do intercropping because the weather did not support. On the other hand, farmers in Nganjuk always planted shallot with monoculture because most farmers thought that it was easier to manage.

For anticipating losses, farmers in Bantul and Nganjuk prefered to use their own seeds from crops 
Table 2. Ex Ante Risk Management Strategy

\begin{tabular}{|c|c|c|c|c|c|}
\hline \multirow{2}{*}{ No } & \multirow{2}{*}{ Description } & \multicolumn{2}{|c|}{$\begin{array}{l}\text { Bantul ( } 2 \text { time/year) } \\
\text { in percentage }\end{array}$} & \multicolumn{2}{|c|}{$\begin{array}{l}\text { Nganjuk (time/year) } \\
\text { in percentage }\end{array}$} \\
\hline & & $\begin{array}{l}\text { Wet land } \\
(\mathrm{n}=50)\end{array}$ & $\begin{array}{l}\text { Coastal sandy } \\
\qquad(\mathrm{n}=27)\end{array}$ & $2(n=30)$ & $\geq 3(n=60)$ \\
\hline \multicolumn{6}{|c|}{$\begin{array}{l}1 \text { Reasons for consistently following the existing crop- } \\
\text { ping system }\end{array}$} \\
\hline & $\begin{array}{l}\text { a. experience has shown that it is the most profitable } \\
\text { crop rotation }\end{array}$ & 20 & 70 & 50 & 72 \\
\hline & b. suitable to local climate & 26 & 11 & 30 & 10 \\
\hline & c. suitable to topography and fertility of land & 10 & - & - & 2 \\
\hline & d. if it is different, it may invite pest attack & 28 & 4 & 13 & 3 \\
\hline & e. to keep of fertility and sustainability & 2 & 15 & 7 & 12 \\
\hline & f. others (group agreement) & 14 & - & - & - \\
\hline \multicolumn{6}{|c|}{2 Shallot production system on first growing season } \\
\hline & a. monoculture & 14 & - & 100 & 100 \\
\hline & b. multiple cropping or sequential cropping & 86 & 100 & - & - \\
\hline \multicolumn{6}{|c|}{$\begin{array}{l}3 \text { Shallot production system on second or other growing } \\
\text { season }\end{array}$} \\
\hline & a. monoculture & 50 & 89 & 100 & 100 \\
\hline & b. multiple cropping or sequential cropping & 50 & 11 & - & - \\
\hline \multicolumn{6}{|c|}{4 Reasons for adopting monoculture production system: } \\
\hline & b. shallot growing is better & $\begin{array}{c}0 \\
16\end{array}$ & $\begin{array}{c}4 \\
37\end{array}$ & 10 & 18 \\
\hline & c. shallot production is higher & 10 & - & 30 & 10 \\
\hline & d. quality of production is better & 4 & - & 7 & 20 \\
\hline & e. profit is more & - & - & 3 & 10 \\
\hline & f. climate is not support to multiple cropping & 24 & 56 & - & - \\
\hline \multicolumn{6}{|c|}{$\begin{array}{l}5 \text { Reasons for adopting the multiple cropping produc- } \\
\text { tion system: }\end{array}$} \\
\hline & $\begin{array}{l}\text { a. in general, it provides higher net income as compared } \\
\text { to mono cropping }\end{array}$ & 48 & 26 & - & - \\
\hline & b. input use, especially land and labor, is more efficient & 18 & 59 & - & - \\
\hline & c. crops are compesating to each other, if one of them & 28 & 11 & - & - \\
\hline & fails & 4 & 4 & - & - \\
\hline \multicolumn{6}{|c|}{ d. shallot grows very well } \\
\hline \multicolumn{6}{|c|}{6 Number of Shallot varieties used: } \\
\hline & a. always single variety in all parcels cultivated & 70 & 96 & 97 & 95 \\
\hline & b. more than one variety in the same parcel cultivated & 10 & - & - & 2 \\
\hline & c. more than one variety in different parcel cultivated & 18 & 4 & 3 & 3 \\
\hline \multicolumn{6}{|c|}{7 Source of shallot seeds: } \\
\hline & a. own-produced & 88 & 78 & 77 & 87 \\
\hline & b. buy from others & 12 & 22 & 23 & 13 \\
\hline \multicolumn{6}{|c|}{$\begin{array}{l}8 \text { Number of locations/parcels cultivated for shallot in a } \\
\text { year: }\end{array}$} \\
\hline & a. only one & 20 & 59 & 77 & 85 \\
\hline & b. more than one & 80 & 41 & 23 & 15 \\
\hline \multicolumn{6}{|c|}{9 All of land was cultivated for shallot: } \\
\hline & a. yes & 80 & 26 & 100 & 97 \\
\hline & b. no & 20 & 74 & - & 3 \\
\hline
\end{tabular}

because it was more economist. If they wanted to buy seed, farmers prefered to buy uncertified seed which was derived from other farmers. The absence of quality assurance and certification of artificial seed from farmers themselves by the government led to lower productivity level achieved than potential productivity of the same variety.

However, farmers in Nganjuk owned farming lands in different locations, they prefered to plant their lands with shallot in the same season $(100 \%$ and $94 \%$ ). On the other hand, farmers in Bantul did not fully plant their lands with shallot. Even in coastal sandy land, farmers (74\%) did not cultivate shallots in the whole farming area.

b. Interactive Risk Management Strategy

Treatments done by farmer for any dead crop 
Table 3. Interactive Risk Management Strategy

\begin{tabular}{|c|c|c|c|c|c|}
\hline \multirow{2}{*}{ No } & \multirow{2}{*}{ Description } & \multicolumn{2}{|c|}{$\begin{array}{l}\text { Bantul ( } 2 \text { time/year) } \\
\text { in percentage }\end{array}$} & \multicolumn{2}{|c|}{$\begin{array}{l}\text { Nganjuk (time/year) } \\
\text { in percentage }\end{array}$} \\
\hline & & $\begin{array}{l}\text { Wet land } \\
(\mathrm{n}=50)\end{array}$ & $\begin{array}{l}\text { Coastal sandy } \\
\quad(\mathrm{n}=27)\end{array}$ & $2(\mathrm{n}=30)$ & $\geq 3(n=60)$ \\
\hline \multicolumn{6}{|c|}{1 If some plants are not survive: } \\
\hline & a. no revoked & 38 & 59 & - & 2 \\
\hline & b. revoked and replanting & 24 & - & 43 & 72 \\
\hline & c. revoked but no replanting & 38 & 41 & 53 & 27 \\
\hline \multicolumn{6}{|c|}{2 Planting distance in the first growing season: } \\
\hline & a. $20 \times 20 \mathrm{~cm}$ & 80 & 4 & - & - \\
\hline & b. $15 \times 20 \mathrm{~cm}$ & 18 & 19 & - & - \\
\hline & c. $15 \times 15 \mathrm{~cm}$ & 2 & 59 & 50 & 15 \\
\hline & d. $15 \times 10 \mathrm{~cm}$ & - & 19 & 3 & 2 \\
\hline & e. $10 \times 10 \mathrm{~cm}$ & - & - & 47 & 83 \\
\hline \multicolumn{6}{|c|}{3 Planting distance in the second growing season or other: } \\
\hline & a. $20 \times 20 \mathrm{~cm}$ & 56 & 81 & - & - \\
\hline & b. $15 \times 20 \mathrm{~cm}$ & 28 & 15 & - & - \\
\hline & c. $15 \times 15 \mathrm{~cm}$ & 10 & 4 & 50 & 15 \\
\hline & d. $15 \times 10 \mathrm{~cm}$ & 6 & - & 3 & 2 \\
\hline & e. $10 \times 10 \mathrm{~cm}$ & - & - & 47 & 83 \\
\hline \multicolumn{6}{|c|}{4 Type of fertilizer used: } \\
\hline & a. just single fertilizer & - & - & - & 2 \\
\hline & $\mathrm{b}$ just compound fertilizer & 10 & - & - & 5 \\
\hline & c. single and compound fertilizer & 30 & - & 40 & 78 \\
\hline & d. single and organic fertilizer & 2 & 37 & 3 & - \\
\hline & e. compound and organic fertilizer & 4 & - & - & - \\
\hline & f. single, compound, and organic fertilizer & 54 & 63 & 57 & 15 \\
\hline \multicolumn{6}{|c|}{5 The use of fertilizer in dry season vs. wet season: } \\
\hline & a. no difference in type and amount & 30 & 7 & 10 & 25 \\
\hline & b. no differene in type, but difference in amount & 34 & 74 & 37 & 20 \\
\hline & c. different in type and amount & 34 & 19 & 53 & 55 \\
\hline \multicolumn{6}{|c|}{6 Tendency of farmers in pest and disease control: } \\
\hline & a. chemical pesticide & 100 & 81 & 100 & 100 \\
\hline & b. botanical pesticide & - & - & - & - \\
\hline & c. chemical and botanical pesticide & - & 19 & - & - \\
\hline & Pest and disease controlling method: & & & & \\
\hline & a. preventive & 38 & 33 & 10 & 48 \\
\hline & b. curative & 18 & 15 & 20 & 7 \\
\hline & c. preventive and curative & 44 & 52 & 70 & 43 \\
\hline & Mixing pesticides in controlling pests and diseases: & & & & \\
\hline & a. yes, as a preventive measure & 28 & 37 & 20 & 48 \\
\hline & b. yes, as a curative measure & 36 & 15 & 10 & 3 \\
\hline & c. yes as a preventive and curative measure & 36 & 48 & 70 & 48 \\
\hline \multirow[t]{5}{*}{9} & Reasons for mixing pesticides: & & & & \\
\hline & a. controlling some pests and diseases simultaneously & 52 & 30 & 63 & 85 \\
\hline & $\begin{array}{l}\text { b. cost-saving effort by mixing expensive pesticide and the } \\
\text { cheap one }\end{array}$ & 4 & 19 & 10 & 8 \\
\hline & $\begin{array}{l}\text { c. trial and error show that theresult of mixing pesticides is } \\
\text { more effective than the use of single pesticide }\end{array}$ & 6 & - & - & 3 \\
\hline & d. time and labor-saving & 38 & 48 & 23 & 3 \\
\hline \multirow[t]{4}{*}{$\overline{10}$} & Actions taken when there is labor shortage: & & & & \\
\hline & a. Maximize family labor & 48 & 44 & 50 & 83 \\
\hline & b. take turn with other farmers in using the available labor & 30 & 33 & 17 & 7 \\
\hline & c. look for hired labor from outside the village & 22 & 22 & 33 & 10 \\
\hline & Actions taken if there is capital shortage: & & & & \\
\hline & a. borrowing from formal institution & 24 & 48 & 53 & 38 \\
\hline & b. borrowing from informal institution & 60 & 48 & 43,3 & 62 \\
\hline & c. selling some assets & 16 & 33 & 3,3 & - \\
\hline
\end{tabular}

were: 1) farmers did not revocate, for it could damage roots from surrounding plants and the worries for spreading disease inside; 2) farmers revocated and replanted with the condition that the crop was under
10 days old. If the crop was more than 10 days old, they did not do replanting, for said crop growth would not be the same as others; and 3) they did revocation, but did not do replanting because it 
Table 4. Ex Post Risk Management Strategy

\begin{tabular}{|c|c|c|c|c|c|}
\hline \multirow{2}{*}{ No } & \multirow{2}{*}{ Description } & \multicolumn{2}{|c|}{$\begin{array}{l}\text { Bantul ( } 2 \text { time/year) } \\
\text { in percentage }\end{array}$} & \multicolumn{2}{|c|}{$\begin{array}{l}\text { Nganjuk (time/year) } \\
\text { in percentage }\end{array}$} \\
\hline & & $\begin{array}{l}\text { Wet land } \\
(\mathrm{n}=50)\end{array}$ & $\begin{array}{l}\text { Coastal sandy } \\
\qquad(n=27)\end{array}$ & $2(n=30)$ & $\geq 3(n=60)$ \\
\hline \multicolumn{6}{|c|}{1 The status of shallot farming in supporting the family: } \\
\hline & a. fully depends on income from shallot farming & - & - & - & 5 \\
\hline & b. mostly depends on income from shallot farming & 84 & 89 & 100 & 95 \\
\hline & c. partly depends on income from shallot farming & 16 & 11 & - & - \\
\hline & d. does not depend on income from shallot farming & - & - & - & - \\
\hline \multicolumn{6}{|c|}{$\begin{array}{l}2 \text { If shallot farming fails, the effort to support the family } \\
\text { will come from: }\end{array}$} \\
\hline & a. income from other farming & 34 & 59 & 23 & 7 \\
\hline & b. to take saving & 10 & 7 & 7 & 13 \\
\hline & $\begin{array}{l}\text { c. borrowing money from other farmers or other } \\
\text { sources }\end{array}$ & 8 & 15 & 13 & 42 \\
\hline & d. looking for additional job & 44 & 19 & 33 & 15 \\
\hline & e. selling some assets & 4 & - & 23 & 23 \\
\hline & 5 \\
\hline & $\begin{array}{l}\text { a. the size of next planting is adjusted to the available } \\
\text { capital } \\
\text { b. adding capital by using part or all of the saving }\end{array}$ & 16 & 19 & - & 13 \\
\hline & c. adding capital by selling some assets & 18 & 15 & 13 & 20 \\
\hline & d. adding capital by borrowing money & 44 & 48 & 30 & 22 \\
\hline & e. borrowing inputs from shops & 4 & 4 & 37 & 40 \\
\hline \multicolumn{6}{|c|}{4 Actions taken following the failure of shallot farming: } \\
\hline & $\begin{array}{l}\text { a. stop cultivating shallot because of the fear repeating } \\
\text { the loss }\end{array}$ & - & - & - & - \\
\hline & $\begin{array}{l}\text { b. keep cultivating shallot and trying to look for the } \\
\text { cause of failure }\end{array}$ & 98 & 96 & 90 & 95 \\
\hline & $\begin{array}{l}\text { c. keep cultivating shallot and without trying to look } \\
\text { for the cause of failure }\end{array}$ & - & - & - & 5 \\
\hline & d. just cultivating on time or safe growing season & 2 & 4 & 10 & - \\
\hline
\end{tabular}

would cause difference in plant growth.

There was a difference in planting distance between growing season in Bantul caused by monoculture intercropping system. In monoculture, most farmers used close plant spacing, although it was also influenced by the size of shallot seeds.

All coastal sandy land farmers used organic fertilizers derived from animal manure, while only a few wetland farmers use it. If they used organic fertilizers, they used manufactured organic fertilizers, such as Petroganik. Even for farmers in Nganjuk who cultivated shallot three times or more in year, there were only 15 percent farmers used organic fertilizer.

In terms of the amount of fertilizer used, there were farmers who used the same type of fertilizer, but at different ammount. The doses in the rainy season usually reduced, especially N (Nitrogen). Organic fertilizers derived from animal manure had the ability to store water too much and long. There were also farmers who used different types and quantities of fertilizer. They did that because of the reason mentioned. On the other hand, farmers in Nganjuk, especially those who planted shallot twice year, would add $\mathrm{ZA}$ and $\mathrm{KCl}$ in the second growing season in order to avoid porous, for shallot will be stored in long-term (5-6 months preparation for seed on first growing season the following year).

On the issue of capital, most farmers in Bantul used capital from Baitul Maal Wa Tamwil (BMT), while farmers in Nganjuk used capital from Bank Rakyat Indonesia (BRI ). According to farmers, borrowing money in BMT was more flexible in terms of collateral and maturity. BMT provided a lag return time at the time of harvest, and if the crop failed, it could be restate and they only had to pay for the administrative costs.

Informal institutions were utilized by farmers if the capital from neighbour, brother, farmer groups, or input agricultural stores was lacking. Researchers did not find a system of ijon (the system of purchasing crops while it was still green and taken at harvest 
time) by middlemen. Form of a loan from agricultural input store was inputs purchased after harvest but it was more expensive than by cash. The debt from agricultural inputs store was mostly done by farmers in Nganjuk.

Farmer groups in Nganjuk also had a function to give credit facility inputs, especially chemical fertilizers. The system used was similar to agricultural input store that was more expensive (dispute of IDR 5000 per sacks) with payment time at harvest. Otherwise, farmers' groups in Bantul provided capital loans to farmers in the form of cash, but in a very limited nominal.

\section{d. Ex Post Risk Management Strategy}

In the event of crop failure, even though farmers have carried out ex ante and interactive risk management strategy, the only option that could be done to overcome the problem of farming was ex-post risk management strategy. Several strategy done by farmers were: a) covering family needs by revenues from other farming; b) finding other occupation; c) selling assets.

According to farmers, shallot farming provided great revenue expectations that become the basis of most of the family income. They would grow shallot constantly in the next period despite the failure in the previous period.

If there were losses, farmers in Bantul who cultivated shallot constantly in which the dominant strategy done was by borrowing cash from formal institutions (preferably BMT) or family relatives. Otherwise, most farmers in Nganjuk would borrow input from agricultural input store. Many stores provided loan capital inputs to farmers in the with the purchasing system after harvest but the price was more expensive than cash.

\section{CONCLUSION}

According to farmers' perceptions, shallot had a high risk in production and prices. Perception of farmers on farming failures included the instability achieved production and financial losses that were caused by fluctuative price. Farmers' decision to follow the dominant cropping pattern and production system reflected ex ante risk management strategies done by farmers as their own respection. In the interactive risk management strategies, farmers tended to use chemical fertilizers which its impact to production was instantly faster than organic fertilizer. In the control of pests and disease, farmers tended to use chemical pesticides by mixing and spraying based on calendar system. Ex post management strategiesis related to each other if the failure in shallot farming to some extent considered to disturb the source of family income and business continuity, then several strategy done by farmers were a) covering family needs by revenues from other farming; $b$ ) finding other occupation; c) selling assets.

\section{ACKNOWLEDGMENT}

This research was supported by Australian Centre for International Agricultural Research and Indonesian Vegetable Research Institute

\section{REFERENCES}

Adiyoga, W dan T.A. Soetiarso. 1999. Strategi Petani dalam Pengelolaan Risiko pada Ushatani Cabai. Jurnal Hortikultura. 8(4): 1299-1311.

Baquet,A., R. Hambleton and D. Jose. 1997. Introduction to Risk Management. USDA Risk Management Agency.

Miller, A., D. Craig, P. James, B. Michael and E. Cole. 2004. Risk Management for Farmers. Staff Paper 04-11. Purdue University: Department of Agricultural Economics.

Musser, W.N. 1998. Risk Management Overview. Paper presented at Mid-Atlantic Risk Management Regional Conference, Williamsburg. August 6-7.

Patrick, G.F., P.H Wilson, P.J. Barry, W.G. Bogges and D.L. Young. 1985. Risk Perceptions and Management Response: Producer-Generated Hypotheses for Risk Modelling. Southern Journal Agriculture Economics.17, 231-238.

Proske, D. and D. Proske. 2008, "Subjective Risk Judgement," In Catalogue of Risks, Springer Berlin Heidelberg, pp. 329-377.

Sen, S. and V. Choudary. ICT in Gariculture, Module 11: Aplication for Agricultural Risk Management. The International Bank for Reconstruction and Development/The World Bank. Washington DC.

Senkondo, E.. 2000. Risk Attitude and Risk Perception in Agroforestry Decision: The Case of Tanzania, Ph.D Thesis. Wageningen Agricultural University.

Sjöberg, L., B. Moen, and T. Rundmo. 2004. Explaining risk perception. An evaluation of the psychometric paradigm in risk perception research. Norway: C. Rotunde Publikasjoner.

Wik, M.S., Holden and E. Taylor. 1998. Risk, Market Imperfections and Peasant Adaption: Evidence from Northern Zambia. Discussion Paper D-28. Department of Economics and Social Sciences, The Agricultural University 

of Norway.

Zinn, J. O. 2009, "Introduction: The Contribution of Sociology to the Discourseon Risk and Uncertainty," In Social Theories of Risk and Uncertainty, Blackwell Publishing Ltd., pp. 1-17. 